ISSN 1392-3196 / e-ISSN 2335-8947

Zemdirbyste-Agriculture, vol. 105, No. 1 (2018), p. 55-62

DOI $10.13080 /$ z-a.2018.105.008

\title{
Screening of early maturing soybean genotypes for production of high quality edible oil
}

\author{
Maja MATOŠA KOČAR, Aleksandra SUDARIĆ, Rezica SUDAR, Tomislav DUVNJAK, \\ Zvonimir ZDUNIĆ \\ Agricultural Institute Osijek \\ Južno predgrađe 17, 31103 Osijek, Croatia \\ E-mail: maja.matosa@poljinos.hr
}

\begin{abstract}
The usage and value of soybean (Glycine $\max$ (L.) Merr.) seed oil are mainly determined by its fatty acid composition, which affects physical, chemical and nutritional properties. In order to assess genotypes' suitability for edible oil production and determine the variability in phenotypic expression of the amount of oil and fatty acid composition in the seed, three-year (2010-2012) trials were set up with eight early maturing advanced soybean lines. As a result, we determined the amount of seed oil and composition of seed fatty acids (palmitic, stearic, oleic, linoleic and linolenic). After analysis of variance ( $A N O V A)$, we calculated the saturated fatty acid (SFA) amount, monounsaturated fatty acid (MUFA) and polyunsaturated fatty acid (PUFA) ratio (MUFA:PUFA) as an indicator of the oxidative stability of the oil, and linoleic and linolenic acids ratio as an indicator of nutritional quality. To give further insight into divergence of given set of genotypes, cluster analysis was performed, while correlation analysis was used to better understand the relationships between all the traits investigated in this research, which play an important role in breeding procedures. The experimental and biometric results indicate the existence of variability in phenotypic expression of investigated traits with significant year and genotype effects, while cluster analysis divided genotypes into two main groups confirming the results of ANOVA. The amount of oil was higher than that obtained in earlier researches conducted in the same geographical region and all averages of five fatty acids coincided with the average values for commercial soybean varieties. MUFA:PUFA was lower than recommended for all tested genotypes, and linoleic and linolenic acids ratio values were higher than the recommended limits for vegetable oils. The results of the correlation study showed the significant and positive relationship between oil and oleic acid, while the significant and negative correlation between oil and both polyunsaturated fatty acids. According to the overall conclusions, the most suitable as a parental component in breeding programs aimed at creating genotypes for the production of edible oil was genotype OS-L-774, while genotypes OS-L-806 and OS-L805 were the least suitable for the same purpose.
\end{abstract}

Key words: fatty acid composition, Glycine max, seed quality, seed oil.

\section{Introduction}

Soybean (Glycine max (L.) Merr.) is the main oilseed crop of the world (FAOSTAT, 2016), recognized as a high-quality source of food and feed, and a significant source of some nutraceutical compounds with many different medical benefits (Cober et al., 2009). Soybean oil is widely used in food industry for the production of many different products such as salad and cooking oils, shortenings and margarine oils, mayonnaise, ice cream and gelatin (El-Shemy, 2011). All of these uses have specific requirements concerning the quality of soybean seed oil, but some common parameters can be used for screening of genotypes in breeding programs aimed at developing varieties used for edible oil production. Along with the amount of oil, such parameters are soybean seed fatty acid composition, saturated fatty acid (SFA) amount, monounsaturated fatty acid (MUFA) and polyunsaturated fatty acid (PUFA) ratio (MUFA:PUFA), linoleic and linolenic acids ratio (linoleic:linolenic acid) as well as correlations between the amount of oil and different fatty acid contents.

The amount of oil in soybean seed can range from $12 \%$ to $24 \%$ of dry matter weight (DM), while most commercial cultivars contain between $19 \%$ and $23 \%$ of DM (Vratarić, Sudarić, 2008). A higher percentage of oil in soybean seed means higher profitability for the oil industry. Nutritional value, stability and taste of soybean oil depend on the fatty acid composition. According to Fehr and Curtiss (2004), average fatty acid values in commercial soybean varieties are $12 \%$ palmitic acid (16:0), 4\% stearic acid (18:0), 27\% oleic acid (18:1), 50\% linoleic acid (18:2) and 7\% linolenic acid (18:3). The most desirable fatty acid phenotypes for

Please use the following format when citing the article:

Matoša Kočar M., Sudarić A., Sudar R., Duvnjak T., Zdunić Z. 2018. Screening of early maturing soybean genotypes for production of high quality edible oil. Zemdirbyste-Agriculture, 105 (1): 55-62 DOI 10.13080/z-a.2018.105.008 
soybean oil nowadays are considered to be those with saturates (palmitic and stearic acid) reduced to less than $7 \%$, linolenic acid reduced to less than $3 \%$, and oleic acid increased to more than $55 \%$, as these have most applications for food, feed and industry. Nevertheless, desired fatty acid composition of oils intended for frying is $7 \%$ saturates, $60 \%$ oleic acid, $31 \%$ linoleic acid and $2 \%$ linolenic acid, while desired fatty acid composition of oils intended for industrial use is $11 \%$ saturates, $12 \%$ oleic acid, 55\% linoleic acid and 22\% linolenic acid (Wilson, 2004).

The main saturated fatty acid in soybean is palmitic acid (16:0), which together with stearic acid (18:0) makes up most of thesaturates in oil. Lowering saturates makes the oil more appealing to food manufacturers and consumers concerned with dietary health issues such as high cholesterol and increased risk of coronary heart disease associated with diets high in saturated fats (Baum et al., 2012).

Unsaturated fatty acids can be monounsaturated (oleic acid) or polyunsaturated (linoleic and linolenic acids). Unsaturated fatty acids which can be synthetized in the human body on its own are considered non-essential (oleic acid), while those that cannot be synthetized are called essential fatty acids (linoleic and linolenic acids) (Johnson, Saikia, 2009). Both linoleic and linolenic acids, but especialy the latter, support cardiovascular, reproductive, immune and nervous systems, and are needed to manufacture and repair cell membranes (Johnson, Saikia, 2009). On the other hand, these PUFAs, susceptible to oxidation, reduce the shelf life of oil, cause low stability at high cooking temperatures and off-flavors (Lee et al., 2007).

Oxidative stability of soybean oil generally decreases with increasing degree of unsaturation (Duh et al., 1999), and it can be assessed by calculating the ratio between MUFA and PUFA content, i.e. the ratio between the amount of oleic acid and the sum of linoleic and linolenic acid amounts (Rani et al., 2007). Soybean oil, in general, has MUFA:PUFA of 0.5 , which means it has poor oxidative stability compared to other vegetable oils such as olive oil and canola oil (Rani et al., 2007). Oxidative stability of soybean oil can be improved by trans-isomer producing catalytic hydrogenation or by breeding for higher amount of oleic acid (MUFA) in soybean oil, which is also known to reduce cholesterol and arteriosclerosis as well as reduce the risk of heart disease (Wilson, 2004; Lee et al., 2007; Rani et al., 2007). Diets rich in trans fatty acids increase the risk of some pathologies, such as cardiovascular diseases (Brouwer et al., 2010), so hydrogenation process as a means of increasing oil stability is nowadays becoming more and more unpopular.

The same way as the oxidative stability of soybean oil can be assessed by MUFA:PUFA, linoleic:linolenic acid can be used to determine its nutritional quality. According to Russo (2009) and Williams et al. (2011), lowering linoleic:linolenic acid value in human diets towards one increases protection against certain degenerative pathologies, but since some of the most common oils in human diets such as soybean, corn, sunflower and safflower are all rich in linoleic acid, the balance between linoleic and linolenic acids can be achieved by incorporating more dietary sources abundant in linolenic acid, such as linseed and rapeseed oil, as well as fish and shellfish (Russo, 2009). As a result of all aforementioned, the changes occurring in consumer preferences for soybean oil and the world market for oilseed products becoming ever more competitive, the emphasis in breeding soybean should be put not only on increasing seed yield as the main objective for all breeding programmes, but also on increasing soybean oil quality and modifying the fatty acid composition to meet the demands of industry and end-users alike (Hemingway et al., 2015). These changes can be achieved by means of conventional breeding and genetic engineering (Fehr, 2007; Cober et al., 2009), both of which require favourable gene pool concerning the given trait. The results of this research giving insight into the amount of oil and fatty acids of some early maturing soybean genotypes would be beneficial for defining parental components in soybean breeding programs, aimed at improving oil quality in the future. This way, genetic enhancement of soybean contributes to advances in food processing industries, improving the added value properties of final soybean products.

\section{Materials and methods}

A three-year (2010-2012) trial was conducted in the experimental fields of the Agricultural Institute Osijek, Croatia with eight early maturing (maturity group 0 ) advanced soybean (Glycine $\max$ (L.) Merr.) breeding lines, all developed and owned by the Agricultural Institute Osijek, Croatia. These eight advanced breeding lines were chosen from a larger set of genotypes on the basis of their superior agronomic preformance considering higher than standard seed yield, seed yield stability in different environments and satisfactory tolerance to diseases and pests. The trial was set up in a randomized complete block design (RCBD) with four replications, basic experimental plot size was $10 \mathrm{~m}^{2}$, between row distance was $50 \mathrm{~cm}$, and within a row seed distance was $2-3 \mathrm{~cm}$. During the vegetation, all conventional tillage and pest management practices were applied, and the trial plots were harvested each year at full harvesting maturity (R8) (Fehr et al., 1971). Each year of the trial after harvest, seed samples were analyzed for the amount of oil and fatty acids.

The mean monthly air temperatures $\left({ }^{\circ} \mathrm{C}\right)$ and the distribution of the total monthly amount of precipitation $(\mathrm{mm})$ for the soybean growing season in years 2010, 2011 and 2012 at the location Osijek, Croatia are presented in Figures 1 and 2 along with respective 1961-1990 climate normals. It is apparent from Figure 1 that average monthly temperatures were higher than average climate normals (1961-1990) in all the three experimental years. Figure 2 shows that conditions in 2010 were much more humid during the soybean growing season than in 2011 and 2012. The first trial year (2010) had more precipitation than 1961-1990 climate normals, while 2011 and 2012 were below precipitation average.

The amount of oil of each genotype was determined from composite dry grain samples on a grain analyzer InfratecTM 1241 (Foss, Denmark) and expressed in \% of grain dry mass (DM). Oil for fatty acid analysis was extracted using the Soxhlet apparatus (Sigma-Aldrich, Germany) with diethyl ether (J.T. Baker, Netherlands) containing butylhydroxytoluene as an inhibitor (Carlo Erba Reagents, Italy). Preparation of fatty acid methyl esters was carried out according to 


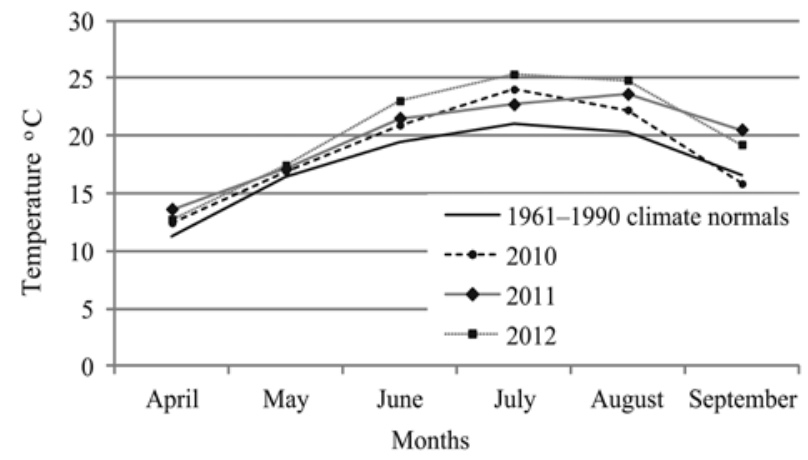

Figure 1. Aveage monthly temperatures in Osijek, Croatia for soybean growing season (April-September) in years 2010-2012 and for soybean vegetation period in 1961-1990 climate normals (Croatian Meteorological and Hydrological Service)

the standard ISO 5509:2000 (boron trifluoride method): the oil was converted to low molecular weight, volatile nonpolar derivatives (e.g., fatty acid methyl esters) after which the fatty acid composition was analyzed by gas chromatography. The fatty acid methyl esters were analyzed using the gas chromatography system GC-2010 Plus ("Shimadzu", Japan), equipped with an autosampler, oven, flame ionization detector (FID) and software $L a b$ solution GC Solution, version 2.32 .00 ("Shimadzu"). Separation was performed on Forte GC ("Shimadzu") column (length $30 \mathrm{~m}$, inner diameter $0.25 \mathrm{~mm}$, film thickness $0.25 \mu \mathrm{m}$ ) and injected sample volume was $1 \mu \mathrm{l}$. Operating conditions were: inlet temperature set at $225^{\circ} \mathrm{C}$, detector temperature set at $250^{\circ} \mathrm{C}$ and carrier gas $\mathrm{He}$ (Vodovod Osijek, Croatia) at a flow rate of $1.24 \mathrm{ml} \mathrm{min}^{-1}$. The initial oven temperature of $150^{\circ} \mathrm{C}$ was held for $7 \mathrm{~min}$, then increased to $240^{\circ} \mathrm{C}$ (held for $1 \mathrm{~min}$ ) at a rate of $8^{\circ} \mathrm{C} \mathrm{min}{ }^{-1}$, and finally increased to $250^{\circ} \mathrm{C}$ and held for $5 \mathrm{~min}$. Total analysis time was 24.29 minutes. Fatty acids were separated according to the number of carbon atoms and number of double bonds. Identification was done by comparing measured retention time to the standard AOCS standard FAME \#3 ("Restek", USA). Fatty acids were quantified using the method of normalization based on peak area.

Results were statistically processed with software STATISTICA 12.0 (StatSoft Inc., USA). The results of the analyses were sorted and used for calculating the coefficient of variation $(\mathrm{CV})$ and for analysis of variance ( $A N O V A)$, and the values were tested with least significant difference (LSD) at $5 \%$ and $1 \%$. To further visualize genotypes' divergence, besides ANOVA used for determining the variability of investigated traits, a grouping of genotypes according to the amount of oil and fatty acids was achieved by pair-wise similarity based on the Euclidean distance, i.e. by cluster analysis. Cluster analysis results are presented by a dendrogram constructed using single linkage method (also known as nearest neighbor clustering). For determining the relationship between the amount of oil and different fatty acids, correlation analysis was used.

\section{Results and discussion}

The range for oil amount in this research (Table 1) was considerably higher than the range (18.9-20.5\% DM) determined in the three-year research conducted

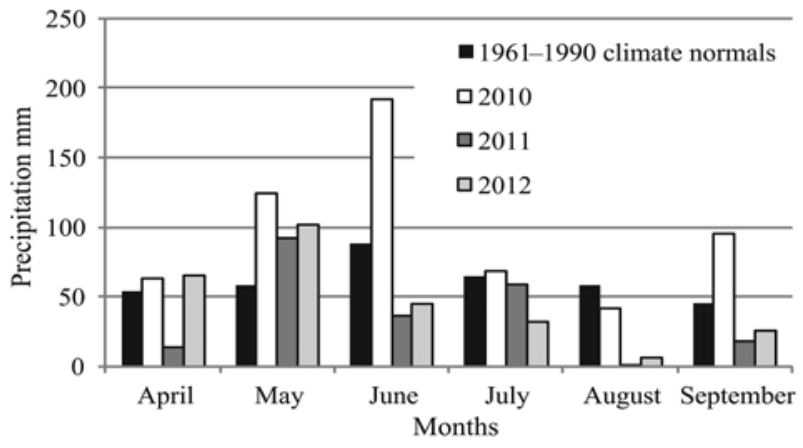

Figure 2. Average total monthly precipitation in Osijek, Croatia for soybean growing season (April-September) in 2010-2012 and for soybean vegetation period in 1961-1990 climate normals (Croatian Meteorological and Hydrological Service)

by Sudarić and Vratarić (2002) also in Osijek (Croatia), on 22 soybean genotypes created at the Agricultural Institute Osijek, Croatia. Beside the differences in plant material, these notably higher values can be due to the fact that two (2011 and 2012) out of three years in our research were extremely favourable for oil production according to Josipović et al. (2013) while this was not the case in the research conducted by Sudarić and Vratarić (2002). Average values for fatty acids were similar to those recorded by Fehr and Curtiss (2004) in commercial soybeans (12\% palmitic acid, $4 \%$ stearic acid, $27 \%$ oleic acid, 50\% linoleic acid and 7\% linolenic acid). The average amount of palmitic acid was somewhat lower than in mentioned research and at the same time, the amount of stearic acid was somewhat higher, as were the amounts of polyunsaturated (linoleic and linolenic) fatty acids. The average amount of oleic acid was notably lower than that reported by Fehr and Curtiss (2004).

The results of $A N O V A$ indicate that the amount of oil and fatty acids varied significantly depending on genotype and environment (Table 2), which agrees with the results of Ghodrati (2013), Rodrigues et al. (2014) and Fan et al. (2015). Year effects were highly significant for all analyzed traits, showing divergence in phenotype caused by different environmental conditions (Table 1). According to Josipović et al. (2013), the amount of oil in soybean seed is higher in years with less precipitation and higher air temperatures at the time of pod forming and dry matter accumulation. This was true for average oil amount values determined in this research where hot and extremely humid 2010 resulted in the lowest average amount of oil in soybean seed, while hot and dry 2011 and 2012 resulted in higher average amounts of oil (Figs 1 and 2, Table 1). According to Bellaloui et al. (2015), cooler temperatures favour synthesis of linolenic acid, while at the same time the synthesis of oleic acid is negatively affected as a result of inverse relationship between them. The same was true in research done by Xue et al. (2008), where increasing air temperature during pod fill significantly increased oleic acid, while significantly decereasing linoleic and linolenic acid concentrations. The inverse relationship of these fatty acids was clearly confirmed in this research where oleic acid was at its highest in hot and dry 2012, while linoleic and linolenic acids had their highest amounts recorded in 2010, which had more modest temperatures and high humidity (Figs 1 and 2, Table 1). 
Table 1. Average amount values and coefficient of variation (CV, \%) for oil (\% DM) and fatty acids (\%) in eight early maturing soybean genotypes (Osijek, Croatia, 2010-2012)

\begin{tabular}{|c|c|c|c|c|c|c|c|}
\hline \multirow{2}{*}{ Genotype } & \multirow{2}{*}{ Year } & \multirow{2}{*}{ Oil } & \multicolumn{5}{|c|}{ Fatty acid } \\
\hline & & & palmitic & stearic & oleic & linoleic & linolenic \\
\hline \multirow{4}{*}{ OS-L-774 } & 2010 & 22.33 & 10.51 & 4.01 & 22.02 & 54.38 & 7.77 \\
\hline & 2011 & 23.56 & 10.06 & 5.21 & 28.91 & 47.37 & 7.03 \\
\hline & 2012 & 26.35 & 11.19 & 5.23 & 25.92 & 49.94 & 6.44 \\
\hline & Mean & $24.08 \mathrm{a}$ & $10.59 \mathrm{~b}$ & $4.81 \mathrm{~cd}$ & $25.62 \mathrm{a}$ & $50.56 \mathrm{~cd}$ & $7.08 \mathrm{ab}$ \\
\hline \multirow{4}{*}{ OS-L-788 } & 2010 & 20.78 & 10.91 & 4.67 & 20.27 & 55.33 & 7.70 \\
\hline & 2011 & 22.21 & 10.48 & 6.34 & 26.91 & 48.32 & 6.68 \\
\hline & 2012 & 24.23 & 10.71 & 5.87 & 25.84 & 50.34 & 6.18 \\
\hline & Mean & $22.41 \mathrm{e}$ & $10.70 \mathrm{~b}$ & $5.63 \mathrm{a}$ & $24.34 \mathrm{ab}$ & $51.33 \mathrm{bcd}$ & $6.85 \mathrm{~b}$ \\
\hline \multirow{4}{*}{ OS-L-793 } & 2010 & 21.71 & 10.49 & 4.25 & 20.46 & 56.03 & 7.76 \\
\hline & 2011 & 22.85 & 9.87 & 4.83 & 23.33 & 53.52 & 7.41 \\
\hline & 2012 & 25.41 & 10.02 & 6.28 & 28.91 & 48.64 & 4.99 \\
\hline & Mean & $23.32 \mathrm{c}$ & $10.13 \mathrm{~cd}$ & $5.12 \mathrm{bc}$ & $24.23 \mathrm{ab}$ & $52.73 \mathrm{~b}$ & $6.72 \mathrm{~b}$ \\
\hline \multirow{4}{*}{ OS-L-794 } & 2010 & 21.38 & 11.52 & 4.41 & 21.39 & 53.22 & 8.17 \\
\hline & 2011 & 23.78 & 10.97 & 4.99 & 24.82 & 50.85 & 7.35 \\
\hline & 2012 & 25.77 & 11.41 & 5.71 & 25.98 & 49.00 & 6.50 \\
\hline & Mean & $23.64 \mathrm{~b}$ & $11.30 \mathrm{a}$ & $5.03 \mathrm{bc}$ & $24.06 \mathrm{ab}$ & $51.03 \mathrm{bcd}$ & $7.34 \mathrm{a}$ \\
\hline \multirow{4}{*}{ OS-L-799 } & 2010 & 21.25 & 11.25 & 4.27 & 24.12 & 51.42 & 7.72 \\
\hline & 2011 & 22.69 & 11.44 & 4.46 & 22.70 & 52.60 & 7.58 \\
\hline & 2012 & 25.08 & 11.14 & 6.46 & 28.58 & 46.37 & 5.99 \\
\hline & Mean & $23.01 \mathrm{c}$ & $11.27 \mathrm{a}$ & $5.06 \mathrm{bc}$ & $25.13 \mathrm{ab}$ & $50.13 \mathrm{~d}$ & $7.10 \mathrm{ab}$ \\
\hline \multirow{4}{*}{ OS-L-800 } & 2010 & 20.86 & 10.54 & 4.29 & 20.82 & 54.73 & 8.47 \\
\hline & 2011 & 22.87 & 10.39 & 5.31 & 24.20 & 51.80 & 6.97 \\
\hline & 2012 & 24.56 & 10.75 & 6.26 & 26.39 & 49.32 & 5.93 \\
\hline & Mean & $22.76 \mathrm{~d}$ & $10.56 \mathrm{~b}$ & $5.29 \mathrm{ab}$ & $23.80 \mathrm{~b}$ & $51.95 \mathrm{bc}$ & $7.12 \mathrm{ab}$ \\
\hline \multirow{4}{*}{ OS-L-805 } & 2010 & 20.42 & 9.57 & 3.86 & 19.51 & 57.20 & 8.65 \\
\hline & 2011 & 22.21 & 9.84 & 4.47 & 21.45 & 55.32 & 7.67 \\
\hline & 2012 & 23.79 & 10.58 & 5.15 & 24.82 & 51.98 & 6.09 \\
\hline & Mean & $22.14 \mathrm{f}$ & $9.99 \mathrm{~d}$ & $4.49 \mathrm{~d}$ & $21.92 \mathrm{c}$ & $54.83 \mathrm{a}$ & $7.47 \mathrm{a}$ \\
\hline \multirow{4}{*}{ OS-L-806 } & 2010 & 20.38 & 10.24 & 3.92 & 18.76 & 58.05 & 7.98 \\
\hline & 2011 & 21.76 & 10.33 & 4.51 & 20.55 & 55.86 & 7.66 \\
\hline & 2012 & 24.12 & 10.65 & 5.30 & 24.84 & 52.42 & 5.68 \\
\hline & Mean & $22.09 \mathrm{f}$ & $10.41 \mathrm{bc}$ & $4.58 \mathrm{~d}$ & $21.38 \mathrm{c}$ & $55.44 \mathrm{a}$ & $7.11 \mathrm{ab}$ \\
\hline \multirow{4}{*}{ Average } & 2010 & $21.14 b$ & $10.63 c$ & $4.21 c$ & $20.92 c$ & $55.05 a$ & $8.03 a$ \\
\hline & 2011 & $22.74 a$ & $10.42 b$ & $5.02 \mathrm{~b}$ & $24.11 b$ & $51.05 \mathrm{~b}$ & $7.29 b$ \\
\hline & 2012 & $24.92 a$ & $10.81 a$ & $5.78 a$ & $26.41 a$ & $49.75 c$ & $5.97 c$ \\
\hline & Mean & 22.93 & 10.62 & 5.00 & 23.81 & 52.25 & 7.09 \\
\hline $\mathrm{LSD}_{\text {(genotype) } 0.05}$ & & 0.24 & 0.31 & 0.41 & 1.81 & 1.76 & 0.41 \\
\hline $\mathrm{LSD}_{\text {(year) } 0.05}$ & & 0.09 & 0.01 & 0.01 & 0.02 & 0.03 & 0.01 \\
\hline CV $(\%)$ & & 1.13 & 2.48 & 7.01 & 6.51 & 2.88 & 4.93 \\
\hline
\end{tabular}

Note. Genotype means with the same letter in superscript are not significantly different; average year values with the same letter in superscript are not significantly different.

The coefficient of variation $(\mathrm{CV})$, as a measure of trait's relative variability in given genotypes, was predictably low (1.13\%) for the amount of oil (Table 1), the same as in the research done by Ghodrati (2013) in Iran on 12 genotypes in three growing seasons. Rodrigues et al. (2010) reported only slightly higher CV values (3.8\%) for oil calculated for 207 families from $\mathrm{F}_{2: 3}$ progenies in Brazil. Among fatty acids, stearic acid had the highest CV value $(7.01 \%)$, making it the most variable, while palmitic acid had the lowest CV value (2.48\%), showing it was the least variable. Primomo et al. (2002) reported the highest $\mathrm{CV}$ values for stearic acid and the lowest for linoleic acid in their three year, four location experiment conducted in Canada with three soybean lines and 14 soybean cultivars. The same fatty acid had the lowest $\mathrm{CV}$ values in researches done by Priolli et al. (2014) in their experiment conducted with 94 soybean accessions over two years in Brazil, and Fan et al. (2015) in their experiment with 200 reccombinant inbred lines and parents conducted over three years in China, but in both of these researches the highest $\mathrm{CV}$ values were determined for oleic acid. Although none of the aforementioned researches were done in the same geographical area or in the same climatic conditions as ours, they all show some degree of variation for the tested traits while differences between determined $\mathrm{CV}$ values depend on the number of genotypes included, as well as on the experiment type (years, locations), where low $\mathrm{CV}$ values are usually more common in small sets of genotypes, i.e. smaller scale experiments as is the case in this study. 
Table 2. Analysis of variance ( $A N O V A$ ) (mean squares and significance) for analyzed traits of the seeds of 8 soybean early maturing soybean genotypes (Osijek, Croatia, 2010-2012)

\begin{tabular}{ccccccc}
\hline \multirow{2}{*}{$\begin{array}{c}\text { Source of } \\
\text { variation }\end{array}$} & Oil & \multicolumn{5}{c}{ Fatty acid } \\
\cline { 3 - 6 } & & palmitic & stearic & oleic & linoleic & linolenic \\
\hline Genotype & $4.12^{* *}$ & $1.35^{* *}$ & $0.83^{* *}$ & $12.84^{* *}$ & $23.03^{* *}$ & $0.35^{*}$ \\
Year & $20.52^{* *}$ & $0.59^{* *}$ & $9.92^{* *}$ & $121.72^{* *}$ & $113.24^{* *}$ & $17.32^{* *}$ \\
\hline
\end{tabular}

$*$ and $* *-p \leq 0.05$ and $p \leq 0.01$, respectively

Pair-wise similarity based on the Euclidean distance between genotypes in terms of the amount of oil and fatty acids (palmitic, stearic, oleic, linoleic and linolenic) divided all genotypes into two main groups with the linkage distance of $>3.3$ (Fig. 3). One group included two genotypes (OS-L-805 and OS-L-806) and the other remaining 6 genotypes, further divided into two major subgroups, first containing genotypes OSL-774 and OS-L-799, and the second one made up of genotypes OS-L-788 and OS-L-800 grouped together, genotypes OS-L-794 and OS-L-793. The formation of two groups in cluster analysis confirms previously determined divergence among eight early maturing soybean genotypes. As cluster analysis is suitable for identification of divergence among genotypes on the

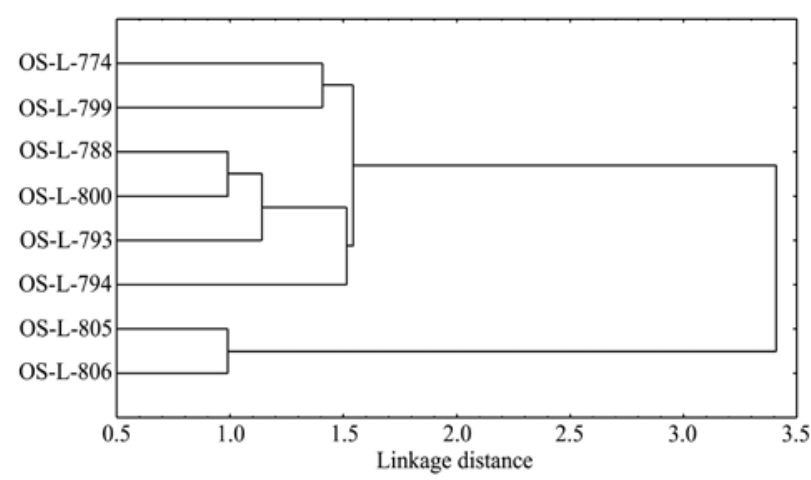

Figure 3. The dendrogram based on the Euclidean distance between eight early maturing soybean genotypes evaluated according to the seed fatty acid and oil composition parameters basis of their pedigree, morphological or agronomic traits (Zhou et al., 2002; Antalikova et al., 2008), it can be used for further confirming the results of ANOVA in preliminary plant breeding researches.

Since it is preferable for soybean oil used in food industry to have lowered amount of saturates (Baum et al., 2012), in order to determine investigated genotypes' suitability for edible oil production, the amount of saturated fatty acids (SFA) was also determined. Average SFA amount was $15.62 \%$, while OS-L-805 had the lowest amount (14.49\%), and genotypes OS-L-799, OS-L-794 and OS-L-788 had the highest amounts $(16.34,16.33$ and $16.33 \%$ ) of saturates (Table 3 ). The difference between these lines can probably be attributed to differences in genotype since all of them were developing in the same environmental conditions. Furthermore, according to the results of pair-wise similarity based on the Euclidean distance between genotypes in terms of all tested parameters (Fig. 3), OS-L-805 belongs to one, while OS-L-799, OS-L-794 and OS-L-788 together belong to another group of genotypes.

The average value for MUFA:PUFA in this threeyear research was 0.40 with genotypes OS-L-774 and OS-L-799 having the highest (0.44), and genotype OSL-806 - the lowest (0.34) MUFA:PUFA values (Table 3). According to Rani et al. (2007), MUFA:PUFA values lower than average, which is 0.5 for soybean, mean less stable final product, i.e. edible oil with shorter shelf life and lower stability for cooking at high temperatures.

Three-year average of linoleic:linolenic acid (7.36) coincided with the average value (7.74) determined in the research conducted by Rani et al. (2007) on

Table 3. The amounts of saturated (SFA, \%) and polyunsaturated (PUFA, \%) fatty acids, MUFA and PUFA ratio and linoleic and linolenic acids ratio in eight early maturing soybean genotypes (Osijek, Croatia, 2010-2012)

\begin{tabular}{ccccc}
\hline Genotype & SFA & PUFA & MUFA:PUFA & $\begin{array}{c}\text { linoleic acid: } \\
\text { linolenic acid } \\
(18: 2):(18: 3)\end{array}$ \\
\hline OS-L-774 & $15.40 \mathrm{c}$ & $57.64 \mathrm{~g}$ & $0.44 \mathrm{a}$ & $7.14 \mathrm{f}$ \\
OS-L-788 & $16.33 \mathrm{a}$ & $58.18 \mathrm{f}$ & $0.42 \mathrm{c}$ & $7.49 \mathrm{c}$ \\
OS-L-793 & $15.25 \mathrm{~d}$ & $59.45 \mathrm{c}$ & $0.41 \mathrm{~d}$ & $7.85 \mathrm{a}$ \\
OS-L-794 & $16.33 \mathrm{a}$ & $58.37 \mathrm{e}$ & $0.41 \mathrm{~d}$ & $6.95 \mathrm{~h}$ \\
OS-L-799 & $16.34 \mathrm{a}$ & $57.23 \mathrm{~h}$ & $0.44 \mathrm{a}$ & $7.06 \mathrm{~g}$ \\
OS-L-800 & $15.85 \mathrm{~b}$ & $59.07 \mathrm{~d}$ & $0.40 \mathrm{e}$ & $7.34 \mathrm{~d}$ \\
OS-L-805 & $14.49 \mathrm{f}$ & $62.31 \mathrm{~b}$ & $0.35 \mathrm{f}$ & $7.79 \mathrm{~b}$ \\
OS-L-806 & $14.99 \mathrm{e}$ & $62.55 \mathrm{a}$ & $0.34 \mathrm{~g}$ & 7.36 \\
\hline Average & 15.62 & 59.35 & 0.40 & 0.02 \\
LSD 0.05 & 0.02 & 0.05 & 0.00 & 10.99 \\
CV $(\%)$ & 6.58 & 6.59 & 19.10 & $\mathrm{e}$ \\
\hline
\end{tabular}

Note. Genotype means with the same letter in superscript are not significantly different. 
77 soybean genotypes during a one-year trial in India, but ranges in the latter one were much wider $(4.72-10.15)$ when compared to the range (6.95-7.85) determined in our trial. According to The American Oil Chemists' Society Lipid Library (AOCS, 2013), these values are higher than optimal ratio of $5: 1$, which means that the oil will have insufficient nutritional quality.

Analysis of the correlation between all traits determined in this research shows that the amount of oil was in a highly significant $(p<0.01)$ and positive correlation with stearic acid $(r=0.51)$, in significant $(p<0.05)$ positive correlation with oleic acid $(r=0.63)$, but in significant $(p<0.05)$ negative correlation with linoleic $(r=-0.56)$ and linolenic $(r=-0.53)$ acids (Table 4$)$. The results were somewhat different in the research conducted by Rani et al. (2007), where oil was in highly significant positive correlation with stearic and linoleic acids, but in negative correlation with oleic acid. Significant and positive correlation between the amount of oil and the amount of oleic acid means both of these parameters can be increased at the same time by breeding. The problem occurs because this also means increasing the amount of saturates, which are unfavourable from a nutritional point of view. The correlation between oleic and linoleic acids was highly significant $(p<0.01)$ and negative $(r=-0.97)$, the same as in some previous studies (Kumar et al., 2004; Rani et al., 2007). The same was true for the correlation between oleic and linolenic acid ( $p<0.01, r=-0.82)$. Since oleic acid is in significant negative correlation with PUFAs, this means MUFA:PUFA could be corrected by breeding for increased amount of oleic acid. Breeding for optimal linoleic:linolenic acid would be more challenging since these two are significantly $(p<0.05)$ and positively correlated $(r=0.73)$. Nevetheless, increasing the amount of linolenic acid which is beneficial for human health, while at the same time increasing the amount of oil and oleic acid would not be possible, since these are negatively correlated (Table 4).

Table 4. Phenotypic correlation coefficients among analysed traits in soybean (Osijek, Croatia, 2010-2012)

\begin{tabular}{|c|c|c|c|c|c|c|}
\hline & Oil & Palmitic & Stearic & Oleic & Linoleic & Linolenic \\
\hline Oil & & ns & $0.51 * *$ & $0.63 *$ & $-0.56^{*}$ & $-0.53^{*}$ \\
\hline Palmitic & & & ns & ns & $-0.35^{*}$ & ns \\
\hline Stearic & & & & $0.87 * *$ & $-0.86 * *$ & $-0.87 * *$ \\
\hline Oleic & & & & & $-0.97 * *$ & $-0.82^{*}$ \\
\hline Linoleic & & & & & & $0.73 *$ \\
\hline
\end{tabular}

Among the tested genotypes OS-L-774 had the highest amount of oil $(23.26 \% \mathrm{DM})$ and oleic acid (25.62\%), while genotypes OS-L-806 and OS-L-805 had the lowest amount of oil $(21.35 \%$ and $21.41 \% \mathrm{DM})$ and oleic acid $(21.38 \%$ and $21.92 \% \mathrm{DM})$, which makes OSL-774 suitable, but OS-L-806 and OS-L-805 should be omitted from the breeding process that aims to develop soybean genotypes with oil favourable for food industry (Table 1). Genotype OS-L-806 also had the highest average PUFA content and the lowest MUFA:PUFA, OS-L-805second highest PUFA and second lowest MUFA:PUFA, while OS-L-774 genotype's average PUFA content was among the lowest, and MUFA:PUFA was the highest, which further supports the previous statement. Genotype OS-L-774 had a near average SFA value, while OS-L806 and OS-L-805 values for undesirable saturates were under average but the amount of linolenic acid wich is beneficial for human health was statistically much higher in the latter two genotypes than in the first one (Table 3 ).

\section{Conclusions}

1. The experimental and biometric results of this three-year study indicate the existence of variability in phenotypic expression of soybean oil and fatty acid amounts among eight early maturing soybean genotypes, with both year and genotype having a significant effect on all tested traits.

2. Mean values for the amount of oil and the amounts of all five analyzed fatty acids coincided with the average values for commercial soybean, but none of them exhibited properties desired in edible oil production, i.e. higher than average oil amount, lower than average amount of saturates, higher than average amount of oleic acid, as well as higher than average linolenic acid amount.

3. In all tested genotypes, monounsaturated fatty acid (MUFA) and polyunsaturated fatty acid (PUFA) ratio (MUFA:PUFA) was lower than what is commonly recommended, which indicates soybean oil produced from these would have lower than desired oxidative stability, i.e. shorter than desired shelf life.

4. The linoleic and linolenic acids ratio values were higher than the recommended limits, which means that the oil would be of lower quality from a nutritional point of view.

5. Among the tested genotypes, OS-L-774 had the highest oil and oleic acid contents, average saturated fatty acid content and the highest MUFA:PUFA, which makes it the most suitable as a parental component in breeding programs aimed at creating genotypes for the edible oil industry. Contrary to this, genotypes OS-L-806 and OS-L-805 were the least suitable for the purpose, since they had the lowest oil and oleic acid contents and the lowest MUFA:PUFA.

\section{Acknowledgements}

This research was carried out in the frame of the project 073-0730489-0344 that is funded by the Ministry of Science, Education and Sport of the Republic of Croatia.

Received 19042017

Accepted 05012018 


\section{References}

1. Antalikova G., Žakova M., Benedikova D. 2008 Characterization of soybean traits variability by cluster analysis. Pol'nohospodárstvo, 54: 45-53.

2. AOCS. 2013. The American Oil Chemists' Society Lipid Library. $\quad<$ http://lipidlibrary.aocs.org/OilsFats/content. cfm?ItemNumber $=39463>$

3. Baum S. J., Kris-Etherton P. M., Willett W. C., Lichtenstein A. H., Rudel L. L., Maki K. C., Whelan J., Ramsden C. E., Block R. C. 2012. Fatty acids in cardiovascular health and disease: a comprehensive update. Journal of Clinical Lipidology, 6: 216-234. https://doi.org/10.1016/j.jacl.2012.04.077

4. Bellaloui N., Bruns H. A., Abbas H. K., Mengitsu A., Fisher D. K., Reddy K. N. 2015. Agricultural practices altered soybean seed protein, oil, fatty acids, sugars, and minerals in the Midsouth USA. Frontiers in Plant Science, 6: 31. https://doi.org/10.3389/fpls.2015.00031

5. Brouwer I. A., Wanders A. J., Katan M. B. 2010. Effect of animal and industrial trans fatty acids on HDL and LDL cholesterol levels in humans - a quantitative review. PLoS ONE, 5 (10).

https://doi.org/10.1371/journal.pone.0009434

6. Cober E. R., Cianzio S. R., Pantalone V. R., Rajcan I. 2009. Soybean. Vollmann J., Rajcan I. (eds). Oil crops. Handbook of plant breeding No. 4. New York, USA, p. 57-90.

7. Duh P.-D., Yen W. J., Yen G.-C. 1999. Oxidative stability of polyunsaturated fatty acids and soybean oil in an aqueous solution with emulsifiers. Journal of American Oil Chemists' Society, 76 (2): 201-204.

https://doi.org/10.1007/s11746-999-0218-9

8. El-Shemy H. A. (ed.). 2011. Soybean and nutrition. Rijeka, Croatia, 476 p. https://doi.org/10.5772/1008

9. Fan S., Li B., Yu F., Han F., Yan S., Wang L., Sun J. 2015. Analysis of additive and epistatic quantitative trait loci underlying fatty acid concentrations in soybean seeds across multiple environments. Euphytica, 206 (3): 689-700. https://doi.org/10.1007/s10681-015-1491-3

10. FAOSTAT. 2016. The Food and Agriculture Organization Statistical Database <http://www.fao.org/faostat/en/\#home>

11. Fehr W. R. 2007. Breeding for modified fatty acid composition in soybean. Crop Science, 47 (3): 72-87. https://doi.org/10.2135/cropsci2007.04.0004IPBS

12. Fehr W. R., Curtiss C. F. 2004. Breeding for fatty acid composition of soybean oil. $7^{\text {th }}$ World Soybean Research Conference, $4^{\text {th }}$ International Soybean Processing and Utilization Conference, $3^{\text {rd }}$ Brazilian Soybean Congress. Foz do Iguacu, Brazil, p. 815-821.

13. Fehr W. R., Caviness C. E., Burmood D. T., Pennington J. S. 1971. Stage of development descriptions for soybeans, Glycine max L. Merrill. Crop Science, 11: 929-931. https://doi.org/10.2135/cropsci1971.0011183X001100060051x

14. Ghodrati G. 2013. Study of genetic variation and broad sense heritability for some qualitative and quantitative traits in soybean (Glycine max L.) genotype. Current Opinion in Agriculture, 2 (1): 31-35.

15. Hemingway J., Eskandri M., Rajcan I. 2015. Genetic and environmental effects on fatty acid composition in soybeans with potential use in automotive industry. Crop Science, 55: 1-11. https://doi.org/10.2135/cropsci2014.06.0425

16. ISO 5509:2000. Animal and vegetable fats and oils Preparation of methyl esters of fatty acids. European Committee for Standardization, Brussels.

17. Johnson S., Saikia N. 2009. Fatty acids profile of edible oils and fats in India. Centre for Science and Environment, New Delhi, India, 48 p.
18. Josipović M., Sudarić A., Sudar R., Plavšić H., Marković M., Jug D., Stojić B. 2013. Influence of irrigation and variety on the soybean grain yield and quality in the no nitrogen fertilization soil conditions. Vukadinović V., Đurđević B. (eds). Soil and crop management: adaptation and mitigation of climate change. Osijek, Croatia, p. 237-245.

19. Kumar V., Rani A., Joshi O. P. 2004. Fatty acid profile released cultivars of Indian soybean with special reference to identification of high comparatively low linolenic and high oleic acid cultivars. The Indian Journal of Agricultural Sciences, 74 (7): 388-391.

20. Lee J.-D., Bilyeu K. D., Shannon J. G. 2007. Genetics and breeding for modified fatty acid profile in soybean seed oil. Journal of Crop Science and Biotechnology, 10 (4): 201-210.

21. Primomo V. S., Falk D. E., Ablett G. R., Tanner J. W., Rajcan I. 2002. Genotype $\times$ environment interactions, stability, and agronomic performance of soybean with altered fatty acid profiles. Crop Science, 42: 37-44. https://doi.org/10.2135/cropsci2002.3700

22. Priolli R. H. G., Campos J. B., Stabellini N. S., Pinheiro J. B., Vello N. A. 2014. Association mapping of oil content and fatty acid components in soybean. Euphytica, 206 (1): 263-278.

23. Rani A., Kumar V., Verma S. K., Shakya A. K., Hussain S. M., Chauhan G. S. 2007. Interrelationship between oil content and fatty acid composition in Indian soybean (Glycine max) cultivars. The Indian Journal of Agricultural Sciences, 77 (3): 59-62.

24. Rodrigues J. I. D., Arruda K. M. A., Cosme Damião Cruz N. D., Piovesan N. D., Barros E. G., Moreira M. A. 2014. Biometric analysis of protein and oil contents of soybean genotypes in different environments. Pesquisa Agropecuária Brasileira, 49 (6): 475-482. https://doi.org/10.1590/S0100-204X2014000600009

25. Rodrigues J. I. D., De Miranda F. D., Ferreira A., Borges L. L., Ferreira M. F. D., Good-God P. I. V., Piovesan N. D., Barros E. G., Cosme Damião Cruz N. D., Moreira M. A. 2010. Mapping QTL for protein and oil content in soybean. Pesquisa Agropecuária Brasileira, 45 (5): 472-480. https://doi.org/10.1590/S0100-204X2010000500006

26. Russo G. L. 2009. Dietary n-6 and n-3 polyunsaturated fatty aids: from biochemistry to clinical implications in cardiovascular prevention. Biochemical Pharmacology, 77: 937-946. https://doi.org/10.1016/j.bcp.2008.10.020

27. Sudarić A., Vratarić M. 2002. Variability and interrelationships of grain quantity and quality characteristics in soybean. Die Bodenkultur, 53 (3): 137-142.

28. Vratarić M., Sudarić A. 2008. Soybeans (Soja). Poljoprivredni institut Osijek, Croatia, 460 p. (in Croatian).

29. Williams C. D., Whitley B. M., Hoyo C., Grant D. J., Iraggi J. D., Newman K. A., Gerber L., Taylor L. A., McKeever M. G., Freedland S. J. 2011. A high ratio of dietary n-6/n-3 polyunsaturated fatty acids is associated with increased risk of prostate cancer. Nutrition Research, 31 (1): $1-8$.

https://doi.org/10.1016/j.nutres.2011.01.002

30. Wilson R. F. 2004. Seed composition. Boerma H. R., Specht J. E. (eds). Soybeans: improvement, production, and uses ( $3^{\text {rd }}$ ed.). American Society of Agronomy, monograph No. 16, p. 621-677.

31. Xue H. Q, Upchurch R. G., Kwanyuen P. 2008. Relationships between oleic and linoleic acid content and seed colonization by Cercospora kikuchii and Diaporthe phaseolorum. Plant Disease, 92 (7): 1038-1042. https://doi.org/10.1094/PDIS-92-7-1038

32. Zhou X., Carter T. E., Cui Z., Miyazaki S., Burton J. W. 2002. Genetic diversity patterns in Japanese soybean cultivars based on coefficient of parentage. Crop Science, 42 (4): $1331-1342$ https://doi.org/10.2135/cropsci2002.1331 
ISSN 1392-3196 / e-ISSN 2335-8947

Zemdirbyste-Agriculture, vol. 105, No. 1 (2018), p. 55-62

DOI $10.13080 /$ z-a.2018.105.008

\title{
Ankstyvosios brandos sojos genotipų atranka siekiant pagaminti aukštos kokybès maistinị aliejų
}

\author{
M. Matoša Kočar, A. Sudarić, R. Sudar, T. Duvnjak, Z. Zdunić \\ Osijek žemės ūkio institutas, Kroatija
}

\section{Santrauka}

Iš sojos sèklų išgaunamo aliejaus fizikines, chemines ir vertingas maistines savybes labiausiai lemia jo riebalų rūgščių sudètis. Siekiant įvertinti genotipų tinkamumą augalinio aliejaus gamybai ir nustatyti aliejaus kiekio bei riebalų rūgščių sudèties sèklose fenotipinès raiškos kintamumą, trejus metus (2010-2012) buvo atliekami eksperimentai su aštuoniomis atrinktomis ankstyvos brandos sojos linijomis. buvo nustatyta sėklų aliejaus procentinis kiekis ir riebalų rūgščių (palmitino, stearino, oleino, linolo bei linoleno) sudètis. Atlikus dispersinę analizę, kaip aliejaus atsparumo oksidacijai rodiklis buvo apskaičiuotas sočiujų riebalų rūgščių kiekis, mononesočiujų riebalų rūgščių (MNRR) ir polinesočiujų riebalų rūgščių (PNRR) santykis, o linolo rūgšties ir linoleno rūgšties santykis - kaip maistinès kokybės rodiklis. Klasterinè analizė buvo atlikta siekiant geriau suvokti tirtų genotipų skirtingumą, o koreliacinè analizè - siekiant geriau suprasti ryšius tarp tirtų požymių, turinčių didelę reikšmę selekcijos procese. Tyrimo rezultatai ir biometriniai duomenys parodè tirtų požymių fenotipinès išraiškos kintamumą ir auginimo metų bei genotipo ịtaką, o klasterinè analizé genotipus suskirste ị dvi pagrindines grupes, kurios patvirtina dispersinès analizès rezultatus. Šio tyrimo metu gautas didesnis kiekis aliejaus nei ankstesnių tyrimų, atliktų tame pačiame geografiniame regione, ir visi penkių riebalų rūgščių vidurkiai sutapo su sojos komercinių veislių vidutinemis vertemis. Visų tirtų genotipų MUFA:PUFA buvo mažesnis nei rekomenduojamas, o linolo bei linoleno rūgščiu santykio vertès buvo didesnès nei augaliniam aliejui rekomenduojamos ribos. Koreliacinè analizė parodè reikšmingą teigiamą ryši tarp aliejaus bei oleino rūgšties ir reikšmingą neigiamą ryši tarp aliejaus bei abiejų polinesočiųu riebalų rūgščių.

Padaryta išvada, kad genotipas OS-L-774 yra tinkamiausias kaip tėvinis komponentas selekcinėse programose, skirtose sukurti genotipus augalinio aliejaus gamybai, o šiam tikslui mažiausiai tinkami pasirode genotipai OS-L806 ir OS-L-805.

Reikšminiai žodžiai: aliejus, Glycine max, riebalų rūgščių sudètis, sėklų kokybė. 